\title{
FREQUENCY AND FACTORS ASSOCIATED WITH TOBACCO SMOKING AMONG YOUNG FEMALE STUDENTS IN PAKISTAN
}

\section{Saima Akhter ${ }^{\unrhd}$, Hassan Mustafa ${ }^{2}$, Usman Ali Warraich ${ }^{3}$, Nadeem Rizvi ${ }^{4}$}

\begin{abstract}
OBJECTIVE: To evaluate the frequency and factors associated with smoking among female university students in Pakistan.

METHODS: This cross-sectional survey was conducted in 4 cities (Karachi, Hyderabad, Multan and Lahore) of Pakistan. A total of 689 female students from I8 universities (including medical, engineering \& social sciences universities) filled the questionnaire through convenient sampling method. Data analysis was done on SPSS 22. Binary logistic regression, with $95 \%$ confidence interval $(\mathrm{Cl})$ was used to determine the factors associated with smoking.
\end{abstract}

RESULTS: Mean age at initiation of smoking was $16.65 \pm 2.46$ years. Total frequency of smoking was $7.4 \%(n=5 \mathrm{I} / 689)$. Out of $5 \mathrm{I}$ students involved in smoking, 25 (49\%) used shisha, 7 (13.7\%) used Cigarette and 19 (37\%) used both modes of smoking. Students who consider smoking necessary for Social gathering are 5 times more prone to smoke. Strong relationship between advertisement on Social media and smoking was found $(p<0.05)$. Female students from fashion, business administration, media Sciences and engineering were more frequently indulge in smoking when compared to medical sciences $(p<0.05)$. Less than $1 \%$ of cigarette smokers and $29.6 \%$ shisha smokers respectively were comfortable doing smoking in front of their parents. In females who were engaged in both kinds of smoking, $52.3 \%$ reported use of shisha before cigarette. Among non-smoker females 19\%frequently visit shisha bar with family and friends.

CONCLUSION: Although overall frequency of smoking was noted to be low among female students but parental approval of shisha, indulgence of shisha smokers in cigarette is alarming and cannot be ignored.

KEY WORDS: Tobacco Smoking (MeSH), Shisha (MesH); Females (MeSH); Universities (MeSH); Students $(\mathrm{MeSH})$; Social Media $(\mathrm{MeSH})$; Frequency (MeSH).

THIS ARTICLE MAY BE CITED AS: Akhter S, Mustafa H, Warraich UA, Rizvi N. Frequency and factors associated with tobacco smoking among young female students in Pakistan. Khyber Med Univ J 20।8; 10(2):76-80.

\section{INTRODUCTION}

W orld Health Organization, in 2008, declared tobacco as the largest preventable cause of death Worldwide.' It is estimated that tobacco kills more than five million people in a year time that is more than tuberculosis, HIV/AIDS and malaria combined. ${ }^{2}$ Statistics suggest that by 2030 , the death toll will exceed eight million a year. The same report states that the tobacco has caused around 100 million deaths in the $20^{\text {th }}$ century.'
Tobacco smoking is a known risk factor for 6 out of 8 major life threatening diseases including ischemic heart diseases, cerebrovascular diseases, chronic obstructive pulmonary disease, and lung cancer. ${ }^{1-4}$ The spectrum of diseases caused by smoking has expanded in females and can additionally lead to breast cancer, cervical cancer, ${ }^{4}$ infertility and obstetrical problems. ${ }^{5}$ Moreover female smoking is also associated with increased rates of adolescent smoking. ${ }^{6}$
$1^{凶}$ Assistant Professor, Pulmonary Department, Ziauddin University and Hospital, Karachi, Pakistan

Email:drsaima_82@hotmail.com

Cell \#: 03212281280

2 House Officer, Chest Medicine, Jinnah Post Graduate Medical Center, Karachi, Pakistan

3 Institute of Business Management, Karachi, Pakistan

4 Head of Department, Chest Medicine, Jinnah Postgraduate Medical Center, Karachi, Pakistan

Date Submitted: October 02, 2016

Date Revised: April 15,2018

Date Accepted: April 17,2018

Mothers are considered as a role model for their children. Kids watching mother's smoking and having parental approval has high prevalence of all kind of smoking. The rising trend of smoking among females is a major health concern but despite being important; the data addressing the pattern of smoking among females from Pakistan is scarce. This study was conducted to evaluate the current frequency, methods and factors associated with smoking among female university students in Pakistan.

\section{METHODS}

\section{Study Design and participants:}

A cross-sectional survey was conducted in 4 metropolitan cities of Pakistan namely Karachi, Hyderabad, Multan and Lahore. Female students from 18 different universities took part in this survey. The universities of different disciplines were incorporated; medical, engineering, media sciences, fashion and business sciences. For data analysis purpose we merge fashion, media sciences and business administration subjects under heading of social sciences. These universities had coeducation system and belonged to both public and private sector. The students belonged to different socio-economic class. Mix sample represented a realistic and generalized data of female university students across Pakistan. The rationale for surveying female students was to compare data from Pakistan to rest of the World. 
TABLE I: SOCIO-DEMOGRAPHIC CHARACTERISTICS OF STUDY POPULATION

\begin{tabular}{|c|c|c|c|}
\hline Characteristics & Group & Frequency & \%age \\
\hline Age of Participant (Years (Mean \pm SD) & $20.17 \pm 4.22$ & & \\
\hline Age at initiation of Smoking Shisha & $16.54 \pm 2.49$ & & \\
\hline Age at initiation of Smoking Cigarette & $16.12 \pm 2.68$ & & \\
\hline \multirow{3}{*}{$\begin{array}{l}\text { Type of Smoking and Its frequency } \\
(n=5 I)\end{array}$} & Shisha & 25 & 49.01 \\
\hline & Cigarette & 7 & 13.72 \\
\hline & Both & 19 & 37.25 \\
\hline \multirow{3}{*}{$\begin{array}{l}\text { Discipline } \\
(n=689)\end{array}$} & Medical & 407 & 59.1 \\
\hline & Engineering & 67 & 9.7 \\
\hline & Social Sciences & 215 & 31.2 \\
\hline \multirow{4}{*}{$\begin{array}{l}\text { Cities } \\
(n=689)\end{array}$} & Karachi & 429 & 62.3 \\
\hline & Lahore & 146 & 21.2 \\
\hline & Hyderabad & 66 & 9.6 \\
\hline & Multan & 48 & 7 \\
\hline
\end{tabular}

Self-completed questionnaires were used as a data collection tool in this survey. The questionnaire consisted of 3 different sections. The introductory section was related to the student's profile including name of city, university, discipline of study and age. The second section consisted of questions related to smoking habits like age of initiation and frequency. Next section assesses the factors influencing their smoking habits. Most of the questions demanded the participant to answer in a simple YES or No.

The sample collection was done by convenient sampling. The students were approached in university campus, mostly outside their classes, in cafeterias, grounds and student lounges, during their free time. In one to one meeting students were explained the aim of study and were assured that individual responses would not be shared on any forum or with the university authorities to maintain the confidentiality. Questionnaires were filled after informed verbal consent. During this period, when students were filling the form, the invigilator was present all times to ensure the full understanding of the questionnaire to the participants. The attitude of the invigilator and the nature of questionnaire were impersonal, encouraging and objective. Questionnaire was manually checked for completeness.

Ethical approval was taken from ethical committee of Jinnah Post Graduate Medical Center, Karachi, Pakistan, an independent and renowned body mostly involved in education and research projects.

Data was analyzed by using SPSS 22 . Mean \pm standard deviation was used for continuous variables in the descriptive analysis. Binary logistic regression, with confidence interval $(\mathrm{Cl})$ of $95 \%$, was used to determine the factors associated with prevalence of smoking. $P$ value less than 0.05 was considered significant.

\section{RESULTS}

In this study, 689 female students from I 8 universities filled the questionnaire.
Mean age of participants were $20.17 \pm 4.22$ years. Overall smoking frequency was found to be $7.4 \%$ $(n=5 I / 689)$. Mean age at initiation of smoking reported by female students was $16.65 \pm 2.46$ years. Out of 51 students involved in smoking, use of shisha smoking in combination or as a single method was $86.3 \%$ (table I).

Average numbers of cigarettes consumed by students were $9.4 \pm 7.9$ per day and average numbers of visits to shisha bar by shisha-smokers were $2.32 \pm 2.08$ per week. Among female students, engaged in both kinds of smoking, 52.3\% reported use of Shisha before cigarette. When asked regarding comfort level while smoking in front of parents and elder siblings, $29.6 \%$ and $<1 \%$ of shisha and cigarette smokers respectively reported smoking with and in front of parents and elder siblings. Another important finding was frequent visits of non-smoker female students; $19 \%$ to shisha bar with family and friends.

A significant difference was found in frequency of smoking among cities

TABLE II: FREQUENCY AND KINDS OF SMOKING IN FOUR CITIES OF PAKISTAN

\begin{tabular}{|c|c|c|c|c|}
\hline \multirow[t]{2}{*}{ Name of City } & $\begin{array}{l}\text { Shisha smokers } \\
\qquad(n=25)\end{array}$ & $\begin{array}{l}\text { Cigarette smokers } \\
\qquad(n=7)\end{array}$ & $\begin{array}{l}\text { Both Shisha and } \\
\text { Cigarette smokers } \\
(n=19)\end{array}$ & $\begin{array}{c}\text { Non-smokers } \\
(n=638)\end{array}$ \\
\hline & n (\%age) & n (\%age) & n (\%age) & n (\%age) \\
\hline Hyderabad $(n=66)$ & $3(4.55 \%)$ & $0(0.00 \%)$ & $3(4.55 \%)$ & 60 (91\%) \\
\hline Karachi $(n=429)$ & $21(4.89)$ & $3(0.69 \%)$ & $8(1.86 \%)$ & $397(92.5 \%)$ \\
\hline Lahore $(n=146)$ & $\mathrm{I}(0.68 \%)$ & $4(2.73 \%)$ & $8(5.48 \%)$ & $133(91 \%)$ \\
\hline Multan $(n=48)$ & $0(0.00 \%)$ & $0(0.00 \%)$ & $0(0.00 \%)$ & $48(100 \%)$ \\
\hline
\end{tabular}


FREQUENCY AND FACTORS ASSOCIATED WITH TOBACCO SMOKING AMONG YOUNG FEMALE STUDENTS IN PAKISTAN

TABLE III: FACTORS ASSOCIATED WITH SMOKING AMONG FEMALE STUDENTS ACROSS PAKISTAN

\begin{tabular}{|c|c|c|c|c|c|}
\hline \multirow{2}{*}{\multicolumn{2}{|c|}{ Factors associated with Smoking }} & \multirow{3}{*}{$\begin{array}{c}\text { Odd Ratio } \\
2.229 \\
\end{array}$} & \multirow{3}{*}{$\begin{array}{c}\text { Sig value } \\
0.007 \\
\end{array}$} & \multicolumn{2}{|c|}{ 95\% C.I for Odd Ratio } \\
\hline & & & & \multirow{2}{*}{$\begin{array}{c}\text { Min } \\
1.245\end{array}$} & \multirow{2}{*}{$\begin{array}{c}\text { Max } \\
3.990 \\
\end{array}$} \\
\hline Have you come across any article & No & & & & \\
\hline $\begin{array}{l}\text { from social media regarding } \\
\text { hazards of smoking }\end{array}$ & Yes & 1.000 & & & \\
\hline \multirow{3}{*}{ Discipline } & Social Sciences & 3.156 & 0.000 & 1.672 & 5.958 \\
\hline & Engineering & 3.111 & 0.012 & 1.285 & 7.528 \\
\hline & Medical & 1.000 & & & \\
\hline \multicolumn{2}{|l|}{ Friends Also Smoking } & 1.283 & 0.322 & 0.784 & 2.100 \\
\hline \multicolumn{2}{|l|}{ Necessary for social gathering } & 5.039 & 0.028 & 1.186 & 21.409 \\
\hline \multicolumn{2}{|l|}{ It is status symbol } & $1.75 \mid$ & 0.149 & 0.818 & 3.749 \\
\hline \multicolumn{2}{|l|}{ Its relax your nerves } & 1.724 & .036 & 1.038 & 2.866 \\
\hline
\end{tabular}

$(p<0.00 \mathrm{I})$. No student from Multan reported to indulge in smoking habit while major proportion of smokers belongs to Karachi and Lahore (table II).

The binary logistic regression model proved few factors positively related with smoking habit. More worthy some to mention are the students who considered smoking necessary for social gathering (table III). These students were 5 times more likely to smoke (OR 5.03, p 0.02) as compared to students who do not consider smoking necessary for social gathering. Students who felt that smoking could help in relaxation of nerves were prone to smoke (OR I.72p 0.03). It is interesting to note that students belonging to social sciences and engineering were 3 times more likely to smoke when compared to medicine discipline.

Students who never came across materials against smoking on social media were twice on risk of participating in smoking practice than students who read these articles (OR 2.22, p 0.007).

\section{DISCUSSION}

Wide variation in smoking prevalence, for both male and female is found among different regions of World. Recent studies show a decline in smoking trend among European men, while an increase has noted among the European females particularly in teenage girls. ${ }^{8}$ The prevalence of male and female smoker is $60.2 \%$ and $6.9 \%$ respectively in China.' In the developing world the trend of smoking is much lower in the female population., Prevalence of smoking among females, "' pattern $^{12}$ and age of initiation of smoking ${ }^{13}$ in present study is comparable to previous data from Pakistan.

Shisha has already proven as a serious threat to the society. ${ }^{6,14,15}$ Results from our data also support this fact. High prevalence of shisha smoking among smokers, in combination or as a single method, and comfort level of female smokers for shisha smoking in front of their families depicts its wide acceptability within the society. Likewise, Egyptians $^{16}$ and Lebanese ${ }^{15,17}$ smokers preferred shisha smoking over cigarette smoking. The present study further showed that group of smokers who indulge in both, shisha and cigarette smoking, more than half of them start shisha smoking first and then lean-to cigarette smoking.

It is worth to mention that $19 \%$ of nonsmokers regularly visited shisha bar with family and friends, rendering them more susceptible to indoor pollution containing high levels of carbon monoxide levels present in shisha bars. ${ }^{18}$ This secondhand smoke exposure is of grave concern to this vulnerable population, because of reported relationship between passive smoking and numerous health related disorders. . $^{1920}$

Previously numerous factors and their causal relationship with smoking had been identified, few to mention are false perception for water pipe smoking, ${ }^{14}$ curiosity, pleasure seeking, peer pressure, stress ${ }^{15}$ and depression. ${ }^{17}$ In this present study, statistically significant factors are Social gathering, relaxation of nerves by smoking, non-medical universities and exposure to antitobacco advertisement on social media.

Interestingly students belonging to nonmedical universities were 3 times more likely to smoke when compared to students from medical universities. We want to highlight this fact because this difference between medical and nonmedical students can be matter of research in future.

In today's era where social media including Facebook, Youtube and Twitter is a pervasive mass medium for communication. ${ }^{2 !}$ Adapting new and widespread anti-tobacco advertisement on social media can be effective and economic strategy to strengthen tobacco control policies. This present study has confirmed that presence of anti-tobacco advertisements on social media has definitive effect on smoking behavior of youngster. This finding is also supported by a study conducted by University of Waterloo. ${ }^{22}$ Success rate for quitting smoking in this project was almost double in young adults who used social media when compared to those who used the traditional methods. ${ }^{22}$ There is a paucity of literature in this important area.

Although confidentiality was assured to the participants during the survey but there is a high possibility of underreporting because of cultural 
reason. ${ }^{7}$ The main limitation of present study was convenient sampling method, while the strength of study was generalizability of data from four different cities and also inclusion of universities of different disciplines.

\section{CONCLUSION}

This study is amongst the first in Pakistan to explore frequency and factors associated with smoking among females. The frequency is low but acceptance of shisha on family level and female indulging in shisha smoking are alarming enough to raise concern. Students belonging to social sciences and engineering are more prone to smoking as compared to medicine discipline. Anti-smoking material on social media played a preventive role in smoking among female students. It is recommended that smoking hazards may be included in non-medical university syllabus and anti-tobacco policy-makers may utilize the social media for anti-smoking campaigns.

\section{ACKNOWLEDGMENT}

Authors are grateful for all the respondents for their valuable time and contribution. Author would like to thank Dr Ujala Javaid, MBBS student from Nishtar College for her help in data collection. We would also like to thank all university managements for their support during data collection.

\section{REFERENCES}

I. World health organization (WHO). WHO report on THE GLOBAL TOBACCO EPIDEMIC; 2008. [Cited on: September 22, 2016] Available from URL: (http://www. who.int/tobacco/mpower/mpower _report_full_2008.pdf).

2. World health organization (WHO). WHO report on the top 10 causes of death; 2014 [Cited on: September 22, 2016] Available from URL: (http://www.who.int/ mediacentre/factsheets/fs3 I0/en/).

3. Parkin DM, BrayF, Ferlay J, Pisani P. Global cancer statistics, 2002. CA cancer J Clin 2005; 55(2):74- 108.

4. US Department of Health and Human Services. The health consequences of smoking: a report of the Surgeon General. Atlanta, GA: US Department of Health and Human Services, Centers for Disease Control and Prevention, National Center for Chronic Disease Prevention and Health Promotion, Office on Smoking and Health 62 (2004).

5. DiFranza JR, Aligne CA, Weitzman M. Prenatal and postnatal environmental tobacco smoke exposure and children's health. Pediatrics 2004; I I3(4 Suppl): I007-I 5.

6. Knishkowy B, Amitai Y. Water-pipe (narghile) smoking: an emerging health risk behavior. Pediatrics 2005 Jul; I I 6(I):el I3-I I 9. DOI: 10.1542/peds.2004-2173.

7. Smith DR, Leggat PA. An international review of tobacco smoking in the medical profession: 1974-2004. BMC Public Health 2007;7:||5. DOI: |0.|I86/|47| 2458-7-II5.

8. Gilmore A, Pomerleau J, McKee M, Rose R, Haerpfer CW, Rotman D, et al. Prevalence of smoking in 8 countries of the former Soviet Union: results from the living conditions, lifestyles and health study. Am J Public Health 2004;94(I 2):2 I 77-87.

9. Gu D, Wu X, Reynolds K, Duan X, Xin X, Reynolds RF, et al. Cigarette smoking and exposure to environmental tobacco smoke in China: the international collaborative study of cardiovascular disease in Asia. Am J Public Health 2004;94(I I): 1972-6.

10. Akl EA, Gunukula SK, Aleem S, Obeid R, Jaoude PA, Honeine R, et al. The prevalence of water pipe tobacco smoking among the general and specific populations: a systematic review. BMC Public health 20II;II:244. DOI: 10.1 I86/|47|-2458-I|-244.
II. Ahmed R, Rizwan-ur-Rashid, McDonald PW, Ahmed SW. Prevalence of cigarette smoking among young adults in Pakistan. J Pak Med Assoc 2008;58(I I):597-60 I.

12. Tariq N, Rizvi F, Rajput AM, Khan A, Afzal M. Frequency and common forms of smoking in Female students of universities of Islamabad. Isra Med J 20। 3; 5(2); 144-7.

13. Ahmed EN, Jafarey NA. Smoking habits amongst medical students of Sind Medical College. J Pak Med Assoc 1983;33(2):39-44.

14. Akl EA, Gaddam S, Gunukula SK, Honeine R, Jaoude PA, Irani J. The effects of waterpipe tobacco smoking on health outcomes: a systematic review. Int J Epidemiol 2010; 39 (3): 834-57. DOI: 10.1093/ije/dyq002.

15. Ward KD, Eissenberg T, Rastam S, Asfar T, Mzayek F, Fouad MF, et al. The tobacco epidemic in Syria. Tob control 2006; I 5( I Suppl):i24-29.

16. Israel E, El-Setouhy M, Gadalla S, Aounel el SA, Mikhail N, Mohamed MK. Water pipe (Sisha) smoking in cafes in Egypt. J Egypt Soc Parasitol 2003;33(3 Suppl): I073-1085.

17. Hammal F, Mock J, Ward KD, Eissenberg T, Maziak W. A pleasure among friends: how narghile (waterpipe) smoking differs from cigarette smoking in Syria. Tob Control 2008 Apr;I7(2):e3. DOI: 10.1136/tc.2007.020529.

18. Akhter S, Warraich UA, Rizvi N, Idrees $\mathrm{N}$ and Zaina F. Comparison of end tidal carbon monoxide $(\mathrm{eCO})$ levels in Shisha (water pipe) and cigarette smoker. Tob Induc dis 2014; I2(I): I0. DOI: 10.1186/ 1617-9625-12-10.

19. Maziak W. The waterpipe: an emerging global risk for cancer. Cancer epidemiol 2013;37(1): I-4. DOI: I0.10I6/j.canep.20I2.10.0I3.

20. Jukema JB, Bagnasco DE, Jukema RA. Waterpipe smoking: not necessarily less hazardous than 
cigarette smoking. Neth Heart J 20 I 4;22(3):9। - 9. DOI: |0.1007/s | 247|-0|3-050|-0.

21. Ghannam J. Social Media in the Arab World: Leading up to the Uprisings of $201 \mathrm{l}$. Center for international media assistance 3 (20I I). [Cited on: September 22, 2016] Available from URL: http://www.cima.ned. org/wp-content/uploads/2015/02/ CIMA-Arab_Social_Media-Report10-25-II.pdf.
22. Baskerville NB, Azagba S, Norman C, McKeown K, Brown KS. Effect of a digital social media campaign on young adult smoking cessation. Nicotine Tob Res 2016;18(3):35I60. DOI: |0.1093/ntr/ntv||9.

\section{AUTHOR'S CONTRIBUTION}

Following authors have made substantial contributions to the manuscript as under:

SA: Concept \& study design, acquisition of data, drafting the manuscript, final approval of the version to be published

HM \& UAW: Acquisition of data, drafting the manuscript, final approval of the version to be published

NR: Critical revision,

MJ: Analysis \& interpretation of data, critical review, final approval of the version to be published

Authors agree to be accountable for all aspects of the work in ensuring that questions related to the accuracy or integrity of any part of the work are appropriately investigated and resolved.

\section{CONFLICT OF INTEREST}

Authors declared no conflict of interest GRANT SUPPORT AND FINANCIAL DISCLOSURE NIL 